\title{
Strategi Lembaga Adat Dalam Pemanfaatan Teknologi Informasi Dalam Pengembangan Pariwisata Di Desa Adat Osing Kemiren
}

\author{
Muthiara Dwi Anggreani' ${ }^{1}$ Isnaini Muallidin² \\ ${ }^{1}$ Fakultas Ilmu Sosial Dan Politik, Universitas Muhammadiyah Yogyakarta \\ ${ }^{2}$ Fakultas Ilmu Sosial Dan Politik, Universitas Muhammadiyah Yogyakarta \\ ${ }^{1}$ Penulis Korespondensi: muthiaradwi@gmail.com
}

\begin{abstract}
This study aims to discuss the strategies carried out by the Osing Kemiren Traditional Institute in tourism development by utilizing information technology. This research departs from the openness of indigenous peoples to accept modernization while preserving the cultural values they profess. This has a significant impact on the welfare of the community through the development of village tourism potential by utilizing information technology. This research is a descriptive qualitative research. The types of data used in this study are primary and secondary data. From the results of the analysis in the discussion, it can be concluded that the strategy of traditional institutions in tourism development by utilizing information technology is quite effective, as evidenced by the increasing number of tourist visits during promotions through social media in Kemiren Village. This strategy lies in the institutional strategy implemented by the traditional institutions of Kemiren Village, but there is one strategy that has not been maximized, namely the resource support strategy, where it is necessary to improve the quality of the workforce to support tourism development in Kemiren Village.
\end{abstract}

Keywords: Strategy, Traditional Institutions, Information Technology, Tourism

\begin{abstract}
Abstrak: Penelitian ini bertujuan untuk membahas mengenai strategi yang dilakukan oleh Lembaga Adat Osing Kemiren dalam pengembangan pariwisata dengan memanfaatkan teknologi informasi. Penelitian ini berangkat dari sebuah keterbukaan masyarakat adat untuk menerima modernisasi dengan tetap melestarikan nilai budaya yang mereka anut. Hal ini membawa dampak yang signifikan bagi kesejarteraan masyarakat melalui pengembangan potensi pariwisata desa dengan memanfaatkan teknologi informasi. Penelitian ini merupakan penelitian kualitatif yang bersifat deskriptif. Adapun jenis data yang digunakan dalam penelitian ini yaitu data primer dan sekunder. Dari hasil analisis pada pembahasan, dapat ditarik kesimpulan bahwasannya strategi lembaga adat dalam pengembangan pariwisata dengan memanfaatkan teknologi informasi cukup efektif, dibuktikan dengan jumlah kunjungan wisatawan yang terus meningkat selama dilakukannya promosi melalui media sosial Desa Kemiren. Strategi ini terletak pada strategi kelembagaan yang diterapkan oleh lembaga adat Desa Kemiren, namun terdapat salah satu strategi yang belum maksimal, yaitu pada strategi pendukung sumber daya, dimana perlu adanya peningkatan kualitas tenaga kerja guna mendukung pengembangan pariwisata di Desa Kemiren.
\end{abstract}

Kata Kunci: Strategi, Lembaga Adat, Teknologi Informasi, Pariwisata

Article History:

Received : 2020-11-14

Revised : 2020-12-16

Accepted : 2020-12-20

\section{PENDAHULUAN}

Desa menjadi salah satu elemen mendasar dalam suatu negara karena bersentuhan langausng dengan masyarakat yang merupakan inti dari sebuah kehidupan berbangsa dan bernegara yang erat kaitannya dengan pelayanan publik (Rozi, Listiawan, \& Hasyim, 2017). Segala hal yang berkaitan dengan desa diatur dalam Undang-Undang Nomer 6 Tahun 2014, undang-undang tersebut juga memuat definisi dari desa dan desa adat, kemudian undang-undang tersebut mengatur tentang hukum dan keberadaan serta wewenang dari desa adat yang selanjutnya dibahas lebih rinci pada Peraturan Menteri Dalam Negeri Nomer 52 Tahun 2014.

Permendagri ini membahas tentang pedoman pengakuan dan perlindungan masyarakat hukum adat. Dijelaskan dalam Permendagri Nomor 52 Tahun 2014 pasal 1(1) bahwa masayrakat hukum adat adalah warga Negara Indonesia yang memiliki karakteristik kehidupan yang khas. Mulai dari cara hidup berkelompok, memiliki hukum adat, memiliki hubungan yang erat dengan lingkungan tempat mereka 
tinggal, memiliki sebuah ikatan kesamaan asal usul dengan leluhur mereka sebelumnya, serta memiliki sistem yang mengatur pranata kehidupan dari berbagai aspek dan dijalankan secara turun temurun.

Desa Kemiren merupakan salah satu desa adat yang berada di Kabupaten Banyuwangi. Tepatnya terletak di Kecamatan Glagah, Kabupaten Banyuwangi, Provinsi Jawa Timur. Desa Kemiren ini terkenal akan budaya dan adat istiadatnya. Secara geneologis dan sosiologis, desa ini masih memperlihatkan tata kehidupan sosiokultural yang sangat kuat. Terutama pada kekuatan nilai tradisional Osing, sehingga desa ini ditetapkan menjadi Desa Adat Osing Kemiren (Ratnasari, 2017).

Desa Kemiren ini memiliki dua lembaga yang berjalan beriringan. Terdapat lembaga formal yang berfungsi untuk mengatur tata pemerintahan desa, terdapat pula lembaga adat yang memiliki fungsi khusus untuk mengatur sistem dan hukum adat. Menurut Perdes Kemiren Nomer 19 Tahun 2015, kedudukan dari Lembaga Pemangku Adat di Desa Kemiren yaitu sebagai suatu wadah organisasi permusyawaratan dan permufakatan Pemangku Adat berada diluar susunan organisasi pemerintahan. Lembaga adat dan pemerintah desa saling bersinergi dalam mengembangkan potensi desa, khususnya pada aspek pariwisata. Desa ini ditetapkan menjadi Desa Adat Wisata Osing Kemiren sejak tahun 1995 dengan dikeluarkannya Surat Keputusan (SK) Bupati Banyuwangi Nomer 0410. Kegiatan pariwisata dan kunjungan wisatwan ke desa ini terus meningkat setiap taunnya. Wisata yang ditawarkan mulai dari wisata kuliner, edukasi, budaya dan festival.

Menurut Ariyanti (2020) jumlah kunjungan wisatawan pada desa adat ini terus meningkat. Jumlah kunjungan wisatawan domestik mencapai 161\% dan kunjungan mancanegara mencapai 210\%. Data ini didukung oleh survey yang dilakukan oleh Dinas Kebudayaan dan Pariwisata Kabupaten Banyuwangi.

Diagram 1 Jumlah Kunjungan Wisatawan Di Banyuwangi

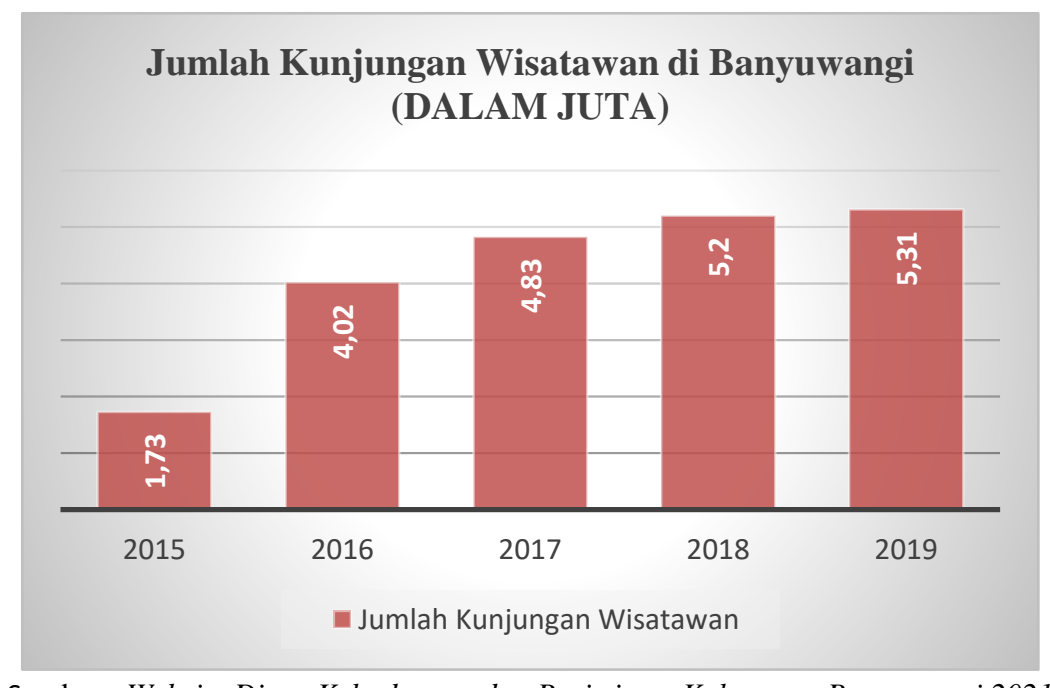

Sumber : Website Dinas Kebudayaan dan Pariwisata Kabupaten Banyuwangi,2021

Hasil survey dari Dinas Kebudayaan dan Pariwisata Kabupaten Banyuwangi yang tertuang dalam data berbentuk diagram diatas menunjukkan bahwa jumlah kunjungan wisatawan terus mengalami peningkatan dari tahun 2015 hingga tahun 2019. Kunjungan wisatawan ini meningkat secara signifikan dari1,73 juta kunjungan pada tahun 2015, menjadi 4,02 juta kunjungan pada tahun 2016. Kemudian terus mengalami peningkatan hingga tahun 2019. Potensi wisata yang sangat besar menjadikan seluruh elemen yang ada di Desa Kemiren bersinergi untuk mengembangkan hal tersebut. Tata kelola Desa Adat Osing Kemiren ini dilakukan secara swakelola, diolah dan di managerial oleh pemangku adat setempat dengan dukungan penuh dari masyarakat (Ariyanti, 2020). Hal menarik yang menjadikan topik ini perlu diteliti yaitu bahwa lembaga pemangku adat di Desa Kemiren sangat menerima dan mendukung modernisasi dengan turut andil dalam memanfaatkan teknologi informasi berupa media sosial Instagram sebagai media pengembangan potensi pariwisata yang mereka miliki. 
Instagram yang digunakan Desa Kemiren untuk media pengembangan pariwisata ini dikelola oleh Kelompok Sadar Wisata (POKDARWIS) Kencana dibawah naungan lembaga adat dan pemerintah Desa Kemiren. Akun instagram dengan username @desa_kemiren ini sudah memiliki jumlah followes sebanyak 7,848 dan memuat 430 postingan. Akun instagram ini terintegritas langsung dengan media sosial dan digital platform lainnya. Adanya pemanfaatan teknologi informasi khususnya media sosial yang digunakan sebagai sarana pengembangan pariwisata ini dapat dikatakan cukup menarik para wisatawan dan menaikkan angka kunjungan wisata. Sehingga fokus penelitian ini akan membahas bagaimana strategi yang digunakan lembaga adat dalam pengembangaan pariwisata dengan memanfaatkan teknologi informasi.

Untuk memudahkan peneliti dalam menjawab permasalahan pada penelitian ini maka digunakan teori strategi yang dikemukakan oleh Jack Kooten dalam Pranata (2019) yaitu :

1. Strategi Organisasi yang berkiatan dengan perumusan visi, tujaun dan insiatif strategi yang baru. Pada strategi ini perlu adanya pembatasan yang dilakukan untuk mengetahui apa yang dilakukan dan untuk siapa hal tersebut dilakukan.

2. Strategi Program yang berfokus pada implikasi-implikasi dari pelaksanaan program tertentu. Strategi ini lebih berfokus pada dampak yang ditimbulkan apabila suatu program dijalankan.

3. Strategi Pendukung Sumber Daya yang membahas tentang bagaimana memaksimalkan sumber daya esensian yang ada untuk meningkatkan kualitas kerja disuatu organisasi. Sumber daya yang dimaksud yaitu mencakup keuangan, peningkatan kualitas tenaga kerja untuk memancing adanya sebuah inovasi.

4. Strategi Kelembagaan yang berfokus pada mekanisme pelaksanaan suatu strategi untuk tercapainya suatu tujuan organisasi

\section{METODE PENELITIAN}

Jenis penelitian yang digunakan adalah penelitian kualitatif dengan pendekatan deskriptif. Jenis penelitian dan pendekatan ini menjadi pilihan peneliti untuk melihat strategi pengembangan pariwisata berbasis teknologi informasi yang dilakukan oleh suatu lembaga adat. Penelitian ini dilakukan di Dusun Kranjan Desa Kemiren Kecamatan Glagah Kabupaten Banyuwangi Provinsi Jawa Timur. Teknik pengumpulan data yang dilakukan yaitu dengan cara wawancara dan studi dokumentasi. Adapun jenis data yang digunakan yaitu data primer yang diperoleh dari hasil wawancara dengan Ketua Lembaga Adat Osing, Kepala Desa Kemiren, Ketua POKDARWIS Kencana dan beberapa masyarkat asli Suku Osing. Kemudian peneliti juga menggunakan data sekunder yang bersumber dari beberapa literatur, sosial media dan website resmi desa kemiren, serta beberapa dokumentasi.

\section{HASIL DAN PEMBAHASAN}

\section{Strategi Organsasi Lembaga Adat Osing Kemiren Dalam Pengembangan Pariwisata}

Ciri dari strategi ini yaitu adanya perumusan visi, tujuan serta sasaran. Strategi ini juga merujuk pada inisiasi agar terbentuknya strategi baru. Kemudian dilakukan pembatasan sasaran guna mengetahui serta membatasi untuk siapa strategi tersebut dilakukan. Penerapan strategi organisasi oleh Lembaga Adat Osing Kemiren yaitu dengan perumusan visi yang berkaitan dengan pengembangan parwisata di Desa Kemiren yaitu, "Menjaga dan melestarikan adat istiadat serta mengenalkan kebudayaan Osing kepada masyarakat luas". Selanjutnya tujuan dari visi yang telah dirumuskan tersebut bahwa selain untuk diwariskan kepada keturunan Suku Osing, juga mengenalkan budaya Osing kepada masyarakat luas. Cara yang dilakukan oleh lembaga adat dalam mewujudkan visinya yaitu salah satunya dengan menjadikan kemiren sebagai desa wisata, kemudian untuk lebih mengenalkan kebudayaan Osing kepada masyarakat di luar Desa Kemiren yaitu dengan mempromosikan dan memberikan informasi mengenai wisata yang ada di Desa Kemiren secara virtual melalui media sosial dan beberapa digital platform yang dimiliki oleh Desa Kemiren. 


\section{Strategi Program Pariwisata Di Desa Adat Osing Kemiren}

Strategi program ini berfokus pada implikasi dari pelaksanaan suatu program. Bagaimana dampak yang dihasilkan dari suatu program yang dijalankan terhadap tujuan organisasi tersebut. Menurut data primer yang bersumber dari hasil wawancara yang dilakukan oleh Ketua POKDARWIS, kegiatan atau program pariwisata yang ada di Desa Kemiren dikelompokkan menjadi wisata budaya, kuliner serta festival.

Tabel 1. Jenis Kegiatan Wisata Desa Adat Osing Kemiren

\begin{tabular}{cll}
\hline No & \multicolumn{1}{c}{ Jenis Wisata } & \multicolumn{1}{c}{ Program Wisata } \\
\hline 1. & Kuliner & Pasar Kampoeng Osing dan Kedai Makanan \\
\hline 2. & Budaya & Pertunjukkan Barong Kemiren \\
\hline 3. & Budaya & Tari Gandrung \\
\hline 4. & Budaya & Pertunjukkan Kesenian Gedogan Othek \\
\hline 5. & Budaya & Pertunjukkan Kesenian Gamelan Banyuwangi \\
\hline 6. & Wisata Mingguan & Selametan Petilasan Buyut Cili \\
\hline 7. & Wisata Mingguan & Latihan Gerak Dasar Tari Tradisi Banyuwangi \\
\hline 8. & Wisata Mingguan & Mocoan Lontar Yusup \\
\hline 9. & Festival & Barong Ider Bumi \\
\hline 10. & Festival & Tumpeng Sewu \\
\hline 11. & Festival & Ngopu Sepuluh Ewu \\
\hline
\end{tabular}

Sumber : kemiren.com, 2021

Tabel 1. menunjukkan jenis kegiatan atau program wisata yang dijalankan oleh pengelola pariwisata Desa Kemiren dengan penjelasan sebagai berikut:

1. Wisata Kuliner : terdapat jenis wisata kuliner di Desa Kemiren. Wisata kuliner tersebut mengajak para wisatawan untuk mencicipi beberapa makanan khas Desa Kemiren seperti Pecel Pithik, Uyah Asem, Klemben, Kucur dan Kopi Jaran Goyang. Para wisatawan dapat menikmati wisata kuliner ini di beberapa kedai makanan yang ada di daerah Desa Kemiren, berkunjung ke Pasar Kampoeng Osing ataupun mengikuti paket wisata yang didalamnya sudah termasuk wisata kuliner.

2. Wisata Budaya : wisata budaya yang ada di Desa Kemiren terdiri dari Barong Kemiren, Gandrung, Gedogan Othek dan Gamelan Banyuwangi. Sama halnya dengan wisata kuliner, para wisatawan yang ingin menikmati kebudayaan Osing dapat memesan paket wisata ataupun berkunjung ke Pasar Kampoeng Osing jika ingin melihat pertunjukkan Gedogan Othek dan Gamelan Banyuwangi secara gratis.

3. Wisata Mingguan : Kegiaatan wisata selanjutnya yaitu wisata mingguan yang terdiri dari

a. Selamaten Petilasan Buyut Cili.

b. Pasar Kampoeng Osing

c. Latihan Gerak Dasar Tari Tradisional Banyuwangi

d. Mocoan Lontar Yusup

4. Festival Tahunan : Terdapat beberapa festival tahunan yang diadakan rutin setiap tahunnya karena memang sudah menjadi adat. Ada juga festival yang diadakan karena tradisi. Beberapa festival tahunan yang ada di Desa Kemiren yaitu :

a. Festival Barong Ider Bumi merupakan upacara adat yang menurut kepercayaan Suku Osing bertujuan untuk menolak bala. Upacara ini biasanya diadakan tanggal 2 syawal atau hari kedua pada Hari Raya Idul Fitri pukul 15.00 WIB.

Rangkaian dari upacara ini diawali dengan kegiatan bersih desa, kemudian arakarakan barong yang diselingi dengan pertunjukkan seni dan ditutup dengan ritual "sembur uthik-uthik" atau menyemburkan uang koin yang sudah dicampur dengan beras kuning dan bunga. 
Pada tahun 2021 ini Barong Ider Bumi dilaksanakan pada Tanggal 14 Mei. Upacara kali ini tidak terbuka bagi wisatawan karena masih dalam masa pandemi covid19, namun para wisatawan dari berbagai daerah tetap bisa menikmati proses upacara adat ini secara virtual yang disiarkan secara langsung melalui official akun instagram@desa_kemiren. Upacara adat ini berlangsung secara khidmat, juga dilakukan dengan menetapkan protokol kesehatan yang sangat ketat.

b. Festival Tumpeng Sewu Tradisi ini rutin dilaksanakan setiap Hari Kamis atau Minggu pada malam pertama Bulan Dzulhidzzah di Desa Kemiren.

c. Festival Ngopi Sepuluh Ewu tradisi ini berasal dari kebiasaan masyarakat Kemiren yang gemar meminum kopi. Desa Kemiren juga memiliki produk kopi sendiri yang diberi nama Kopi Jaran Goyang.

Program-program wisata yang telah dijelaskan tersebut juga tersedia dalam bentuk paket wisata. POKDARWIS Kencana sebagai pengelola pariwisata Desa Kemiren menawarkan beberapa paket wisata yang dapat dipilih oleh para wisatawan. Mendukung suatu program guna pengembangan pariwisata, pengelola pariwisata di Desa Osing Kemiren juga memperhatikan tiga dari liam komponen yang dikemukakan oleh Cooper dkk dalam Sunarto (2013). Tiga komponen tersebut yaitu Attraction, Accessibility, dan Amenities :

1. Attraction : suatu daya tarik wisata yang mencakup keunikan dan daya tarik wisata berbasis alam, budaya maupun buatan/artificial. Berdasarkan informasi yang termuat dalam e-katalog pariwisata Desa Adat Osing Kemiren objek daya tarik wisata yang ditawarkan oleh Desa Kemiren yaitu mencakup rumah adat osing, pertunjukkan kesenian seperti tari gandrung, kuntulan, gedogan, burfah, barong dan angklung paglak, suasana persawahan dan kearifan lokal seperti selametan tumpeng sewu, nyelameti sawah dan barong ider bumi.

2. Accessibility : sarana dan transportasi yang memudahkan wisatwan untuk mengakses destinasi wisata. Pengurus pariwisata Desa Adat Osing Kemiren juga memperhatikan aspek ini dan termuat dalam e-katalog yang juga menjadi buku panduan pariwisata. Untuk mengakses wisata di Desa Kemiren, terdapat empat transportasi yang tersedia di Kabupaten Banyuwangi.

Terdapat sebuah stastiun dengan jarak $\pm 4,1 \mathrm{~km}$ dari desa. Selanjutnya terdapat terminal bus dengan jarak $\pm 6,5 \mathrm{~km}$. Tidak hanya transportasi darat, wisatawan yang berasal dari luar Pulau Jawa juga dapat menggunakan jalur udara maupun laut, karena di Kabupaten Banyuwangi sendiri terdapat bandar udara yang terletak $\pm 21 \mathrm{~km}$ dan pelabuhan dengan jarak $\pm 15,3 \mathrm{~km}$ dari Desa Kemiren. Semua transportasi tersebut dapat dilanjutkan dengan menggunakan ojek baik online maupun offline untuk dapat sampai didestinasi wisata.

3. Amenities : fisilitas penunjang dan pendukung wisata. Desa Kemiren sendiri memiliki 55 homestay yang dikelola langsung oleh masyarakat desa, penginapan, restoran, toko oleh-oleh, jaringan internet, dan toilet umum. Desa Kemiren memiliki 55 bangunan homestay milik masyarakat setempat yang juga berada dibawah manajemen POKDARWIS Kencana. Selain dapat memanfaatkan peta lokasi ini, para wisatawan juga dapat memesan homestay melalui aplikasi seperti Traveloka dan Agoda. Homestay-homestay yang ada di Desa Kemiren ini sudah terdapat dalam dua aplikasi tersebut sejak tahun 2018. Mendaftarkan homestay milik masyarakat lokal ke aplikasiaplikasi tersebut merupakan salah satu program kerja dari POKDARWIS Kencana, dengan terdaftarnya homestay Desa Kemiren di aplikasi online tentunya memudahkan para wisatawan yang ingin mencari penginapan selama berwisata di Desa Kemiren.

Melalui beberapa program wisata yang telah dijelaskan, juga dengan fasilitas penunjang pariwisata yang ada di Desa Kemiren, melahirkan implikasi bagi seluruh elemen masyarakat Kemiren. Implikasi pertama yaitu tentunya tercapainya suatu tujuan organisasi, baik tujuan dari lembaga pemangku adat, POKDARWIS maupun pemerintah desa. Salah satu tujuan yang 
tercapai yaitu mengenai kesejahteraan Suku Osing. Kesejahteraan tersebut dapat dikatakan tercapai karena dari program-program pariwisata tersebut dapat meningkatkan perekonomian masyarakat. Berikut omset pariwisata Desa Kemiren :

Diagram 2 Omset Pokdarwis Kencana Kemiren

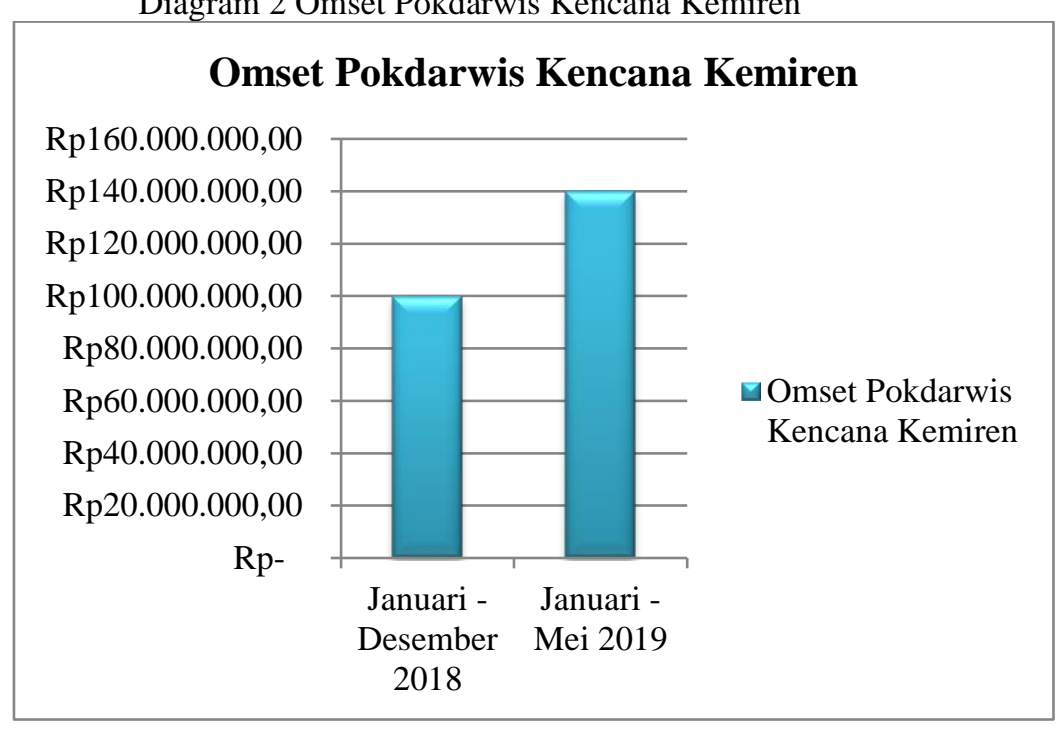

Sumber: Dokumen Desa Osing Kemiren, 2020

Diagram 2 memperkuat implikasi dari program wisata yang telah dijalankan di Desa Kemiren. Diagram tersebut menunjukkan data mengenai pendapatan POKDARWIS Kencana selama mengelola pariwisata di Desa Kemiren selama dua tahun, terhitung sejak awal tahun 2018 hingga pertengahan tahun 2019. Pada bulan Januari hingga Desember 2018 omset POKDARWIS adalah sebanyak Rp 100.000.000,00 kemudian mengalami peningkatan pada bulan Januari hingga Mei 2019 menjadi Rp 140.000.000,00. Omset yang diperoleh POKDARWIS ini tentunya dikelola dengan baik. Omset yang masuk langsung didistribusikan dengan pihak pengelola pariwisata yang lain seperti warga pemilik homestay, rumah makan, para seniman dan juga disalurkan sebanyak 30\% ke BUMDes Kemiren. Selain peningkatan pendapatan yang ditunjukkan diagram 2, peningkatan ekonomi di Desa Kemiren juga dapat dicirikan salah satunya dengan terbentuknya lapangan kerja bagi masyarakat (Yulianti, 2020). Implikasi dari program-program pariwisata yang ada di Desa Kemiren tentunya juga membuka lapangan pekerjaan bagi masyarakat.

Implikasi pertama yang diterima langsung oleh Suku Osing semenjak Kemiren dijadikan desa wisata yaitu dengan terbukanya lapangan pekerjaan. Salah satunya dengan terbentuknya pasar kuliner dan warung makan. Pasar kuliner ini diberi nama Pasar Kampoeng Osing. Selain dijadikan sebagai objek wisata kuliner, pasar ini juga dibentuk dengan tujuan untuk meningkatkan pengembangan masyarakat yang pada akhirnya dapat membantu meningkatkan perekonomian masyarakat di Desa Kemiren. Kemudian impikasi yang ditimbulkan semenjak Kemiren dijadikan sebagai desa wisata yaitu lebih memperhatikan lingkungan sekitar dan menjaga kebersihan. Adanya fasilitas toilet umum dan pemeliharaan sanitasi di kawasan rumah adat Sukosari menambah kesadaran masyarakat dibidang kebersihan lingkungan. Hal ini juga menjadi poin yang sangat penting, karena dari dampak tersebut dapat terciptanya sistem pariwisata berkelanjutan yang tentu dampaknya akan lebih terlihat pada tahun-tahun yang akan datang.

Dampak positif lain yang ditimbulkan karena Kemiren dijadikan sebagai desa wisata juga dirasakan oleh kaum muda. Generasi muda yang ada di Kemirenpun bukan hanya mendapatkan 
penghasilan secara mandiri tetapi terus meningkatkan pengembangan dibidang seni dan dapat dikatakan juga sebagai bentuk aksi dalam menjaga serta melestarikan adat budaya yang mereka miliki. Selanjutnya implikasi yang ditimbulkan dari program serta pengelolaan pariwisata di Desa Kemiren bukan hanya keuntungan materil untuk masyarakat saja. Namun hal ini membawa dampak baik juga bagi nama Desa Kemiren. Semenjak dijadikan desa wisata dengan program yang terus dikembangkan, Kemiren mendapat banyak penghargaan dari pihak pemerintah.

Dari hasil pembahasan yang didukung data wawancara yang telah dipaparkan, dapat dikatakan bahwa strategi program yang dijalankan pada bidang pariwisata di Desa Kemiren ini membawa banyak dampak positif, baik untuk seluruh lapisan masyarakat desa maupun bagi nama Desa Kemiren itu sendiri.

\section{Strategi Pendukung Sumber Daya Dalam Pengembangan Pariwisata Di Desa Adat Osing Kemiren}

Strategi ini berfokus pada hal-hal yang bekaitan dengan peningkatan sumber daya esensial seperti sumber keuangan, peningkatan kualitas tenaga kerja dan sebuah inovasi untuk pengembangan pariwisata itu sendiri. Tiga variabel dalam strategi ini terus dikembangankan dan menjadi perhatian utama dalam pengembangan pariwisata Desa Adat Osing Kemiren.

1. Sumber Keuangan: Pengelolaan pariwisata di Desa Kemiren ini memiliki banyak sumber keuangan yang digunakan untuk pengembangan wisata. Menurut data primer yang bersumber dari hasil wawancara dengan ketua POKDARWIS Kencana menyebutkan bahwa sumber keuangan untuk pengembangan pariwisata di Desa kemiren yaitu berasal dari Anggaran Pendapatan dan Belanja Desa (APBDES), Anggaran Pendapatan dan Belanja Negara (APBN), Badan Usaha Milik Negara (BUMN), Perusahaan Swasta, Donatur dan para wisatawan. Dari sumber keuangan diatas, karena POKDARWIS ini berada dibawah naungan Badan Usah Milik Desa (BUMDes) Kemiren, maka sebanyak 30\% pendapatan akan disalurkan ke BUMDes tersebut. Selanjutnya, karena pengelolaan pariwisata ini bersinergi langsung dengan masyarakat, seperti homestay dan wisata kuliner, maka keuntungannya langsung diterima oleh masyarakat. Selanjutnya pemasukan dari paket wisata akan dikelola oleh POKDARWIS untuk pengembangan dan perawatan program. Sumber keuangan tersebut juga sudah mencakup untuk anggaran perawatan sanggar seni.

2. Peningkatan Kualitas Tenaga Kerja : Tenaga kerja atau pengelola wisata menjadi strategi pendukung yang memiliki peran sangat penting, karena pengelola ini yang langsung berhubungan dengan para wisatawan dan mengatur segala kepentingan pariwisata. Di Desa Kemiren sendiri, yang menjadi tenaga kerja dalam bidang pariwisata yaitu Kelompok Sadar Wisata yang diberi nama POKDARWIS Kencana dan beranggotakan 23 orang.

POKDARWIS ini terbentuk sejak Juli 2017 yang secara resmi diundangkan dengan Surat Keputusan Kepala Desa Kemiren. Kemudian surat keputusan penetapan perubahan susunan kepengurusan POKDARWIS Kencana tersebut diperbaharui dengan Surat Keputusan Kepala Desa Kemiren Nomor : 188/26/429.503.02/2020. Menurut surat keputusan tersebut Kelompok Sadar Wisata (POKDARWIS) merupakan suatu cara alternatif dari pengembangan pariwisata melalui berbagai macam kegiatan seperti pembinaan kelompok swadaya dan swakarsa masyarakat serta berfungsi sebagai penggerak pengembangan dan pembangunan pariwisata. POKDARWIS ini memiliki program kerja yang sudah disusun secara rinci untuk direalisasikan setiap tahunnya. Program kerja yang dirumuskan merupakan suatu upaya dalam pencapaian visi misi serta tujuan yang sudah dirumuskan sebelumnya. Untuk pengembangan pariwisata di 
Desa Kemiren, perlu adanya suatu pengembangan dari pengelola pariwisata itu sendiri. Pengurus pariwisata di Desa Adat Osing Kemiren tentunya sangat memperhatikan hal ini. Kemampuan dari para anggota POKDARWIS yang berperan sebagai pengelola di Desa Kemiren terus ditingkatkan dan mengikuti kebutuhan dari pariwisata itu sendiri. Pemerintah desa memberikan pelatihan dan pendampingan untuk para pengelola pariwisata, selain itu terdapat juga upgrading skill yang rutin dilaksanakan yaitu pada bidang administrasi dan pelatihan pengembangan homestay.

Hal ini dilakukan karena kemampuan tersebut sangat dibutuhkan dalam mengurus pariwisata di Desa Kemiren, terutama pada bagian administrasi karena mayoritas latar belakang pendidikan para pengelola pariwisata tidak berasal dari fokus tersebut. Implikasi dari hal tersebut yaitu kurang terorganisirnya administrasi pada pengelolaan pariwisata di Desa Kemiren, data kunjungan wisata dan omset yang didapat masih kurang tertata sehingga upgrading skill dibidang administrasi menjadi suatu hal yang sangat perlu diperhatikan dalam pengembangan pariwisata di Desa Kemiren. Selain peningkatan kemampuan pengurus organisasi, strategi ini juga menyebutkan mengenai adanya inovasi bagi bidang yang berkaitan, dalam hal ini POKDARWIS Kencana juga memiliki beberapa inovasi yang digunakan sebagai salag satu faktor pendukung pengembangan wisata di Desa Kemiren. Beberapa inovasi yang memang sudah dijalankan seperti pembuatan e-katalog pariwisata, pengembangan digital ekonomi kreatif dengan memasarkan produk UMKM seperti kopi khas Kemiren.

\section{Strategi Kelembagaan Dalam Pengembangan Pariwisata Di Desa Adat Osing Kemiren}

Strategi ini berfokus pada mekanisme pencapaian tujuan suatu organisasi. Pada strategi ini, dapat dijelaskan bagaimana mekanisme yang dijalankan oleh lembaga adat dalam mencapai tujuan yaitu pengembangan pariwisata dengan mengenalkan budaya Osing kepada masyarakat luar. Mekanisme yang dijalankan oleh lembag adat dalam strategi ini yaitu dengan memanfaatkan teknologi informasi sebagai media untuk mengenalkan budaya Osing kepada masyarakat luas, sekaligus sebagai media promosi dalam kegiatan pariwisata. Pada proses pelaksanaan strategi ini, mekanisme yang dilakukan oleh Lembaga adat yaitu berkolaborasi dengan POKDARWIS Kencana sebagai pengelola pariwisata sekaligus pengelola akun media sosial Desa Kemiren. Kemudian lembaga adat juga berkolaborasi dengan pemerintah desa setempat. Hubungan sinergitas lembaga ini dapat digambarkan dengan bagan berikut :

Bagan 1 Mekanisme sinergitas lembaga di Desa Adat Osing Kemiren Dalam Pengembangan Pariwisata

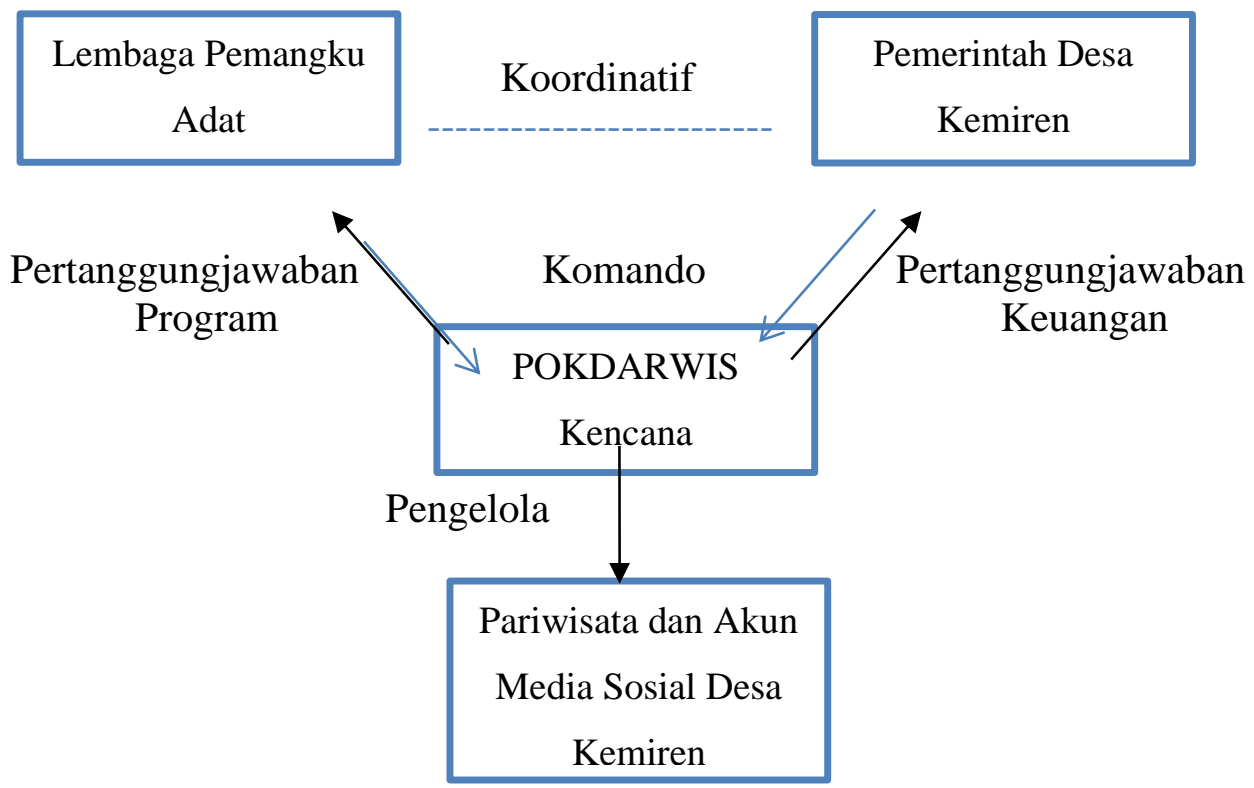


Bagan 1. tersebut menggambarkan mekanisme kolaborasi yang dijalankan oleh lembaga adat dengan pemerintah desa dan POKDARWIS dalam strategi kelembagaan. Lembaga pemangku adat berperan sebagai aktor utama yang menjaga dan melestarikan adat istiadat serta mengenalkan budaya Osing pada masyarakat luas untuk pengembangan pariwisata dengan output kesejahteraan Suku Osing, selanjutnya pemerintah desa berperan sebagai mitra lembaga adat dalam mewujudkan pengembangan pariwisata tersebut dengan menyediakan sumber daya pendukung seperti keuangan, memfasilitasi pelatihan untuk pengembangan skill para pengurus pariwisata dan menyediakan media sosial serta digital platform yang digunakan sebagai media mengenalkan budaya Osing sekaligus sebagai media promosi pariwisata Desa Kemiren. Kemudian POKDARWIS mempunyai fungsi sebagai pengelola pariwisata sekaligus akun media sosial Desa Kemiren yang digunakan untuk keperluan pengembangan pariwisata. Untuk mewujudkan pengambangan pariwisata yang optimal, lembaga adat dan pemerintah Desa Kemiren membentuk sebuah kelompok sadar wisata (POKDARWIS Kencana) yang berperan sebagai pengelola pariwisata sekaligus pengelola seluruh media sosial serta digital platform milik Desa Kemiren untuk pengembangan pariwisata.

Dewasa ini pemanfaatan teknologi informasi menjadi sebuah strategi dalam pengembangan pariwisata, khususnya sebagai media untuk memperkenalkan dan mempromosikan suatu objek pariwisata (Novitasari, 2016). Hal menarik dari Desa Kemiren ini adalah keterbukaan masyarkatnya yang dapat dikatakan $90 \%$ masih masyarakat asli Suku Osing. Stratgi yang dilakukan oleh Desa Kemiren dalam pengelolaan pariwisata berbasis teknologi informasi ini memanfaatkan sosial media dan digital platform seperti website dan beberapa aplikasi seperti instagram, youtube, whatsapp serta google maps. Menurut Wirawan (2013) mengatakan bahwa pemanfaatan teknologi informasi dalam pengembangan pariwisata dilakukan dengan cara menginput data tentang objek wisata ke sosial media, menginformasikan tantang amenitas objek wisata, menginformasikan tentang akses menuju tempat wisata, menyebarkan informasi seputar event pariwisata yang diselenggarakan dan memuat informasi tentang seni budaya dan tradisi di kawasan wisata.

Teknologi informasi yang digunakan Desa Kemiren dalam pengembangan pariwisata yaitu aplikasi instagram. Desa Kemiren memilih aplikasi instagram sebagai media untuk membranding pariwisata. Akun instagram dengan username @desa_kemiren ini sudah dibentuk sejak tahun 2015. Untuk memaksimalkan pengembangan pariwisata di Desa Kemiren, pengelola pariwisata membuat akun instagram ini terintegrasi langsung dengan beberapa aplikasi dan digital platform milik desa seperti website desa, aplikasi whatsapp, email, google maps dan youtube. Teknologi informasi yang dipilih Desa Kemiren untuk mempromosikan pariwisata adalah media sosial yang sudah terintegrasi dengan berbagai digital platform dan aplikasi lainnya. Seluruh media yang digunakanpun cukup aktif dalam memeberikan informasi, bahkan sudah mampu memberikan wisata virtual untuk para wisatawan. Masifnya penggunaan media sosial sebagai sarana promosi pariwisata sangat berpengaruh terhadap jumlah kunjungan wisatawan di Desa Kemiren. Namun semenjak adanya pandemi covid-19 juga sangat berpengaruh terhadap kunjungan wisata.

Terjadi penurunan jumlah wisatawan di tahun 2020 lalu, bahkan pemerintah desapun sempat menutup desa bagi wisatawan. Hal ini dibuktikan dengan data kunjungan wisata yang disajikan dalam diagram berikut : 
Diagram 3 Jumlah Pengunjung Wisata Desa Kemiren

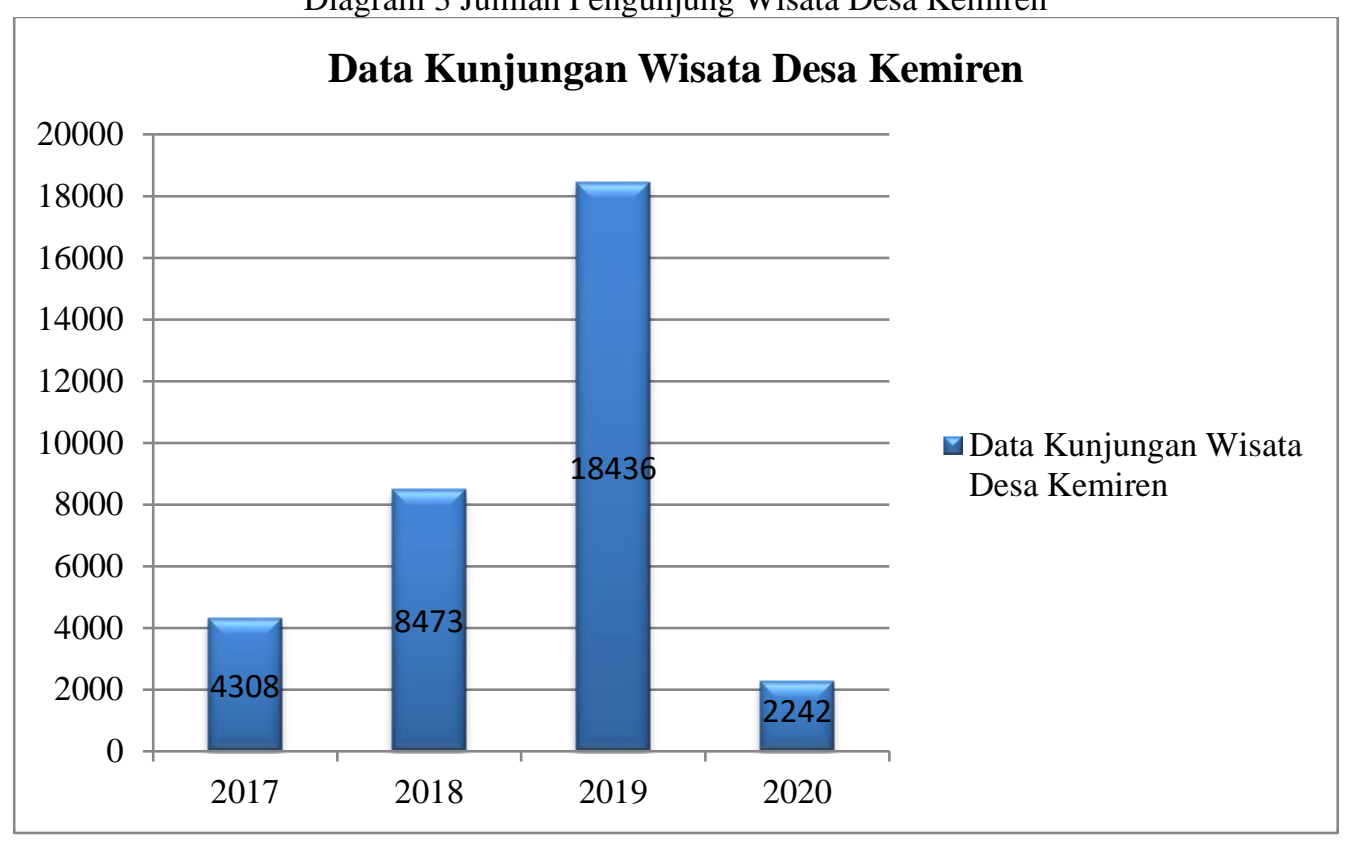

sumber: Dokumen Desa Osing Kemiren

Diagram 3 tersebut menampilkan data kunjungan wisata di Desa Kemiren dalam waktu 4 tahun, dimulai dari tahun 2017 hingga tahun 2020. Dapat dilihat jumlah wisatawan terus meningkat dari tahun 2017 hingga tahun 2019. Hal ini tentunya berkaitan dengan promosi pariwisata yang dilakukan oleh pengelola wisata Desa Kemiren dengan memanfaatkan teknologi informasi. Pada tahun 2017 wisatawan yang berkunjung ke Desa Kemiren tercatat sebanyak 4.308 orang pengunjung, selanjutnya mengalami kenaikan pada tahun 2018 yaitu sebanyak 8.473 orang pengunjung. Jumlah pengunjung terbanyak ditunjukkan pada tabung grafik ke tiga, di tahun 2019 jumlah kunjungan wisata Desa Kemiren mengalami kenaikan yang sangat signifikan hingga mencapai 18.436 orang pengunjung. Jumlah kenaikan wisatawan ditahun ini juga berkaitan dengan event-event besar yang diselenggarakan oleh pengelola pariwisata Desa Kemiren. Selanjutnya terjadi penurunan kunjungan wisata pada tahun 2020. Hal ini terjadi karena adanya pandemi covid-19. Jumlah kunjungan wisata di Desa Kemiren hanya sebanyak 2.242 orang pengunjung.

Pemerintah desa juga sempat menutup kunjungan wisata selama 6 bulan lamanya, terhitung sejak bulan April hingga September 2020. Terlepas dari penurunan jumlah wisatawan yang berkunjung ke Desa Kemiren, namun semenjak memanfaatkan berbagai sarana teknologi informasi sebagai media untuk mengenalkan budaya Osing sekaligus media untuk mempromosikan pariwisata di Desa Kemiren, jumlah kunjungan wisata terhitung sejak tahun 2017 sampai 2019 terus mengalami kenaikan. Bahkan pada tahun 2019 jumlah wisatawan yang berkunjung mencapai belasan ribu. Hal ini membuktikan bahwa strategi yang digunakan secara sinergi oleh lembaga adat, pemerintah desa dan POKDARWIS dengan memanfaatkan teknologi informasi dalam pengembangan pariwisata cukup efektif. Selanjutnya hal ini juga berdampak langsung pada kenaikan perekonomian masyarakat, ketika jumlah kunjungan wisatawan mengalami penaikan maka jumlah pendapatan masyarakat juga akan meningkat.

\section{KESIMPULAN DAN SARAN}

Strategi Lembaga Adat Dalam Pemanfaatan Teknologi Informasi Dalam Pengembangan Pariwisata Di Desa Adat Osing Kemiren berdasarkan pada 4 variabel yang digunakan yaitu strategi organisasi, strategi program, strategi sumber daya pendukung dan strategi kelembagaan maka lembaga adat Osing Kemiren sudah menerapkan secara efektif tiga dari empat variabel 
tersebut untuk pengembangan pariwisata. Keempat indikator tersebut saling berhubungan, mulai dari perumusan visi dan tujuan, cara merealisasikan visi tersebut, pendukung dalam merealisasikan visi tersebut hingga hal-hal yang perlu terus diperhatikan dan ditingkatkan demi pencapaian visi yang maksimal. Terdapat satu variabel yang memiliki peran penting dalam pengembangan pariwisata di Desa Kemiren, yaitu strategi kelembagaan. Strategi ini cukup efektif dalam pengembangan potensi pariwisata di Desa Kemiren yang dilakukan dengan cara memanfaatkan teknologi informasi sebagai media promosi pariwisata sehingga dapat meningkatkan jumlah kunjungan wisatawan dan berorientasi pada peningkatan pendapatan Suku Osing melalui kegiatan pariwisata, sedangkan penerapan strategi sumber daya pendukung masing kurang efektif karena masih terdapat beberapa kekurangan pada pengembangan kualitas tenaga kerja dan inovasi.

Berikut saran dari peneliti berdasarkan analisis dan pembahasan yang telah dikaji terkait Strategi Lembaga Adat Dalam Pemanfaatan Teknologi Informasi Dalam Pengembangan Pariwisata Di Desa Adat Osing Kemiren yaitu sebagai berikut: Perlu adanya peningkatan pada bagian pengembangan kualitas tenanga kerja dengan terus melaksanakan upgrading skill secara rutin, terutama pada bidang administrasi agar data mengenai pariwisata bisa lebih tertata dengan rapih. Lebih memperbanyak inovasi dalam pengembangan pariwisata, seperti mulai memberlakukan penggunaan e-money yang sudah direncanakan untuk setiap transaksi pariwisata di Desa Kemiren agar lebih memudahkan para wisatawan di masa pandemi covid19.

\section{DAFTAR PUSTAKA}

Ariyanti, I. D. (2020). Dampak Sosial Ekonomi Pengembangan Desa Wisata Osing Kemiren Kecamatan Glagah Banyuwangi (Doctoral dissertation, Program Studi Ekonomi Pembangunan Jurusan Ilmu Ekonomi dan Studi Pembangunan Fakultas Ekonomi dan Bisnis Universitas Jember).

Budi, B. S. (2018). Upaya Pengenalan Budaya Suku Osing Melalui Festival Ngopi Sepuluh Ewu dan Dampaknya Terhadap Kehidupan Sosial Ekonomi (Studi Deskriptif Pada Kegiatan Festival Ngopi Sepuluh Ewu Bagi Masyarakat Suku Osing di Desa Kemiren Kecamatan Glagah Kabupaten Banyuwangi).

David, F. R. (2013). Strategic Management: Concepts and Cases: A Competitive Advantage Approach. Pearson.

Firmansyah, A. (2017). Strategi BUMDES Kemangi Dalam Pengembangan Desa Wisata Pada Desa Kemiren Kecamatan Glagah Banyuwangi.

Herdiansyah, H. (2010). Metodologi Penelitian Kualitatif Untuk Ilmu-Ilmu Sosial. Jakarta: Salemba Humanika, 8.

Hunger, J. D., \& Wheelen, T. L. (2003). Essentials of Strategic Management (Vol.4). NJ: Prentice Hall.

Indiarti, W. (2015). Kajian Mengenai Desa Kemiren Sebagai Penyangga Tradisi dan Kearifan Lokal Masyarakat Osing. dalam Anasrullah (ed), Jagat Osing : Seni, Tradisi dan Kearifan Lokal Osing, hlm, 2015, 139-156.

Indiarti, W., \& Munir, A. (2016). Peran dan Relasi Gender Masyarakat Using Dalam Lakon Barong Kemiren-Banyuwangi. Patrawidya, 17(1), 81-103.

Indiarti, W., \& Munir, A. (2016, May). The Implementation of Community-Based Ecotourism Concept in Osing Tourism Village Development Strategy of Banyuwangi Regency, Indonesia. In Asia Tourism Forum 2016-the 12 ${ }^{\text {th }}$ Biennial Conference of Hospitality and Tourism Industry in Asia. Atlantis Press. 
Kodhyat, H. (1983). Pengertian Pariwisata dan Kepariwisataan.

L Didik, S. U. H. A. R. T. A. D. I. (2020). Peran Lembaga Adat Tana Samawa (Lats) Dalam Melestarikan Kearifan Lokal di Kabupaten Sumbawa (Studi di Desa Motong Kecamatan Utan) (Doctoral dissertation, Universitas_Muhammadiyah_Mataram).

Mabruri, K., \& Prawati, I. (2019). Implementasi Desa Adat Osing Dalam Mengembangkan Potensi Pariwisata di Desa Kemiren Kecamatan Glagah Kabupaten Banyuwangi. Publika, 7(6).

Markus, A., Nayoan, H., \& Sampe, S. (2018). Peranan Lembaga Adat Dalam Menjaga Keamanan dan Ketertiban Masyarakat di Desa Salurang Kecamatan Tabukan Selatan Tengah Kabupaten Kepulauan Sangihe. Jurnal Eksekutif, 1(1).

Martono, N. (2011). Metode Penelitian Kualitatif Analisis dan Analisis Data Sekunder.

Marwini, M. (2020, June). Pemanfaatan Teknologi Informasi Dalam Promosi Pariwisata Kecamatan Wonotunggal Kabupaten Batang. In Seminar Nasional Kolaborasi Pengabdian Masyarakat UNDIP-UNNES 2019 (Vol. 1 No. 1).

Mas'ud, A., Safarrudin, S., \& Falziah, F. (2017). Persepsi Pengelola Keuangan Desa Dalam Mewujudkan Transparansi dan Akuntabilitas Keuangan Desa di Kecamatan Mawasangka Kabupaten Buton Tengah. Jurnal Akuntansi dan Keuangan, 2 (2).

Muljadi, A. J., \& Nurhayati, S. (2002). Pengertian Pariwisata. Kursus Tertulis Pariwisata Tingkat Dasar. Modul I.

Musenaf, D. (1995). Manajemen Usaha Pariwisata.

Oka, A. Yoeti. (2008). Ekonomi Pariwisata: Introduksi, Informasi, dan Implementasi. Jakarta: Kompas.

Permadi, A. U. H. P., \& Kholifah, E. (2019). Sinergitas Pemerintah dan Masyarakat Dalam Upaya Pengembangan Desa Wisata (Studi di Desa Wisata Adata Osing Kemiren Kecamatan Glagah Kabupaten Banyuwangi). Sadar Wisata, 2(1), 11-18.

Pranata, Y. N. (2019). Strategi Mencegah Money Politic Melalui Desa Anti Politik Uang (Studi Kasus Pada Gerakan Desa Anti Politik Uang Murtigading Kecamatan Sanden Kabupaten Bantul).

Putro, M. A. P., Soepeno, B., \& Puji, R. P. N. (2019). Barong Using: Optimalisasi Seni Pertunjukan Barong Sebagai Obyek Pariwisata Budaya Using Tahun 1996-2018. Gondang: Jurnal Seni dan Budaya, 3(2), 56-73.

Ratnasari, P. (2017). Musik Gedogan di Desa Kemiren Kabupaten Banyuwangi (Tinjauan Sejarah dan Perkembangan). Solah, 7(1).

Rozi, F., Listiawan, T., \& Hasyim, Y. (2017). Pengembangan Website dan Sistem Informasi Desa di Kabupaten Tulungagung. JIPI (Jurnal Ilmiah Penelitian dan Pembalajaran Informatika), 2(2).

Sugiyono. (2020). Metode Penelitian Kualitatif ( $3^{\text {rd }}$ ed). Alfabeta.

Sunaryo, B. (2013). Kebijakan Pembangunan Destinasi Pariwisata: Konsep dan Aplikasinya di Indonesia (No. 1). Penerbit Gava Media Kebijakan Pembangunan Destinasi Pariwisata: Konsep dan Aplikasinya di Indonesia.

Utama, A. A. G. S., Hikmawati, E. E., Herwiyanti, E., \& Fatmah, F. (2019). Evaluasi dan Pengembangan Sistem BUMDes Wisata Kemiren Berbasis Web Studi Kasus www.kemiren.com. Ekuitas: Jurnal Pendidikan Ekonomi, 7(1), 33-40. 
Wachyuni, S. S., \& Prakoso, A. G. (2018). Model Pengembangan Desa Wisata Berbasis Kearifan Lokal Studi Kasus di Desa Wisata Adat Osing Kemiren Banyuwangi.

Wahyudiono, A. (2019). Kajian Bahasa Osing Dalam Modernitas. FKIP e-Proceeding, 71-86.

Warsita, B. W. B. (2014). Landasan Teori dan Teknologi Informasi Dalam Pengembanga0n Teknologi Pembelajaran. Jurnal Ternodik, 84-96.

Wirawan, S. (2013). Pengembangan Sektor Pariwisata Berbasis Teknologi Informasi.

Yulianti, D. (2020). Dampak Pengembangan Pariwisata Terhadap Kesejahteraan Masyarakat (Studi Kasus Pada Masyarakat Pelaku Usaha di Sekitar Objek Wisata Pantai Tanjung Setia, Pekon Tanjung Setia Kec. Pesisir Selatan Kab. Pesisir Barat)(Doctoral dissertation, IAIN Metro).

Supratikno, H., \& Widjaja, A. W. (2003). Advanced Strategic Management: Back to Basic Approach. Cetakan Pertama. Jakarta: PT Gramedia Pustaka Utama. EISSN.

https://banyuwangitourism.com, diakses pada tanggal 25 September 2020, pukul 14:25 WIB.

https://instagram.com/desa_kemiren, diakses pada tanggal 10 September 2020, pukul 18:10 WIB.

https://kemiren.com, diakses pada tanggal 10 September 2020, pukul 18:15 WIB.

Undang-Undang Nomor 6 Tahun 2014 Tentang Desa.

Peraturan Desa Kemiren Nomor 19 Tahun 2015 Tentang Lembaga Adat.

Peraturan Menteri Dalam Negeri Nomor 52 Tentang Pedoman Pengakuan dan Perlindungan Masyarakat Hukum Adat. 